\title{
An Ethnomedicinal Survey of Medicinal Plants Used as Food Supplements by the Chakma Tribe of Bandarban District, Bangladesh
}

\author{
Mohammed Rahmatullah ${ }^{1 *}$, Abu Hanif ${ }^{1}$, Md. Shahadat Hossan', \\ Md. Ariful Haque Mollik ${ }^{1}$, Taufiq Rahman ${ }^{2}$, Majeedul H. Chowdhury ${ }^{3}$, Rownak Jahan ${ }^{1}$ \\ ${ }^{\prime}$ Department of Biotechnology \& Genetic Engineering, University of Development Alternative, \\ Dhanmondi, Dhaka-1205, Bangladesh. \\ ${ }^{2}$ Department of Pharmacology, University of Cambridge, Tennis Court Road, CB2 1PD, Cambridge, UK. \\ ${ }^{3}$ New York City College of Technology, The City University of New York, Broooklyn, NY 11201, USA
}

\begin{abstract}
Medicinal plants serve as food supplements and provide essential nutrients to the body in addition to their use as prophylactic and curative measures for some diseases. We conducted a survey among the traditional healers of the Chakma tribe, which is the largest tribe in the Chittagong Hill Tracts region in the southeast part of Bangladesh with the objective of obtaining information on plants, which can serve as food supplements. Information was obtained from the traditional healers with the help of a semi-structured questionnaire and the guided field-work method. It was observed that several medicinal plants or plant parts are used as food supplements by the tribe. The plants included Aegle marmelos, Coccinia grandis, Hyptis suaveolens, Mangifera longipes, Nymphaea nouchali, Terminalia chebula, and Syzygium cumini. The plants serve as food supplements and plant parts can be taken on a regular basis for treatment and prevention of several diseases.
\end{abstract}

Key words: Ethnopharmacology, Chakma tribe, Bangladesh, medicinal plants, food supplements

\section{Introduction}

Medicinal plants have been used for centuries as food supplements or ingredients of food. The latter use includes spices and herbs to impart flavour or colour to foods as well as for dietary benefits to aid digestion or in make food more palatable. Recent years have witnessed an explosion in the use of nutraceuticals where extracts, decoctions or direct consumption of medicinal plant or plant parts in the form of pills, capsules, powders and tablets take place. A number of studies have been carried out which point to the beneficial effect of medicinal plants or plant parts when taken as food supplements. Thus these plants can serve as "functional foods", i.e. having the additional properties of promoting health or preventing diseases in addition to their property of supplying nutrients to the body. For instance, it has been reported that oat and bean products are particularly effective cholesterol-lowering agents (1). It is to be noted that oat is also regularly eaten in many countries as a cereal, while beans are taken as vegetables. As such, these plants are important for direct consumption or as supplements to regular diet. A Netherlands Cohort Study showed that consumption of onions has an inverse relationship to incidences of stomach carcinoma (2). Various edible herbs like Serenoa repens, Pygeum africanum, Urtica dioica radix, and Cucurbita peponis semen have shown promise in the treatment of benign prostatic hyperplasia (3). Some plants, which are taken as food supplements like Coccinia indica, Gymnema sylvestre, Aloe vera and Momordica charantia, show promise for glycemic control in diabetes (4).

The practice of using medicinal plants as food supplements, as a preventive measure or to treat diseases is common throughout the world. In the indigenous health care delivery system of Ethiopia, a number of plant species are used to treat ailments associated with pyrexia. Two of the common

* Corresponding Author: Email: rahamatm@hotmail.com 
plants are Ocimum suave and Ocimum lamiifolium (5). A study concluded high levels of herbal supplement use among US women, which was generally associated, with higher education and income, and health needs (6). Smallanthus sonchifolius (yacon) and Lepidium meyenii (maca) were the traditional crops of the original population of Peru and are still used by them as folk medicines. In between them, the two plants have shown considerable potential for the treatment of hyperglycemia, kidney problems and for skin rejuvenation, cytoprotective activity, fertility enhancer, aphrodisiac, adaptogen, immunostimulant, and to influence hormonal balance (7). A study conducted in Turkey concluded that a number of important herbs in the Turkish flora, which are used for edible purposes contain active components effective for increasing human health and for preventing cancer (8). Kim et al (9) reported Adenophora triphylla (a wild plant of Korea) leaves as a potential source for functional foods and a natural source of antioxidants. The plant is commonly used in food materials and in oriental medicine for its analgesic, anti-inflammatory and antitussive properties (9).

Bangladesh is a small developing country with poor resources and a population of about 150 million. A significant percentage of the population live in rural areas and have a high poverty level with earnings of less than US\$ 1 per day. Malnutrition is prevalent in the rural areas and urban slums with consequent high incidence of diseases arising from poor hygiene and malnutrition. Access to medical facilities is also poor in rural areas. Traditional medicinal practitioners form the primary health-care providers to the rural population and a substantial segment of the urban population. These practitioners, as well as the rural population rely on a number of medicinal plants, herbs and weeds to supplement food sources and for preventive measure or cure for a variety of ailments. Bangladesh also has a number of tribes residing in the northern and south-eastern forest regions of the country. Tribal people, in general are more dependent on plants and plant parts which are edible and can serve medicinal purposes. The Chakma tribe is the largest tribe residing in the Chittagong Hill Tracts region in the southeastern part of Bangladesh. They have their own tribal medicinal practitioners and distinctive food habits, which are different from the mainstream population. The tribal medicinal practitioners possess considerable expertise on medicinal plants.. The objective of the present study was to conduct an ethnomedicinal survey of the Chakma tribal healers of Chittagong Hill Tracts Region. The criteria for selecting a medicinal plant as food supplement were edibility, nutritive value (i.e. whether the plant has been reported to be a good source of macro- as well as micro-nutrients), whether the plant or plant part is used directly as food or supplemental food by the Chakmas as well as in other regions of Bangladesh, reports of pharmacological activities in plants or plant parts, and finally whether any toxic reports are present on consuming the plant for short-term or extended time periods.

\section{Materials and Methods}

\section{Area of survey}

Surveys were conducted amongst the Chakma tribal healers residing in Gundum, Tombru and Naikhongchhari villages in the Bandarban district of the Chittagong Hill Tracts region of Bangladesh from January 2008 till February 2009. There are Chakma settlements in all the three villages mentioned above. Bandarban district falls roughly between $92^{\circ} 10^{\prime}-92^{\circ} 40^{\prime} \mathrm{E}$ and $21^{\circ} 20^{\prime}-22^{\circ} 20^{\prime} \mathrm{N}$ and has an area of 4479 square kilometers. The district consists mostly of forests and hills. Annual average temperature ranges from a minimum of $13^{\circ} \mathrm{C}$ to a maximum of $34.6^{\circ} \mathrm{C}$. Annual rainfall is in the range of 303 centimeters. The Chakmas form the largest tribe amongst the various tribal groups residing within the district. The main agricultural crops of the district are paddy, mustard, and vegetables while the main fruits cultivated are bananas, pineapples, jack-fruits, oranges and papayas.

\section{Mode of information collection}

Informed consent was obtained from the Chakma healers prior to collection of any data. Interviews were conducted in the Chakma language with the help of an interpreter. Two healers were interviewed at Tombru and one each at Gundum and Naikhongchaari. At their request, the two uest of 
healers of Gundum were interviewed together. A semi-structured questionnaire was used during the interview process. The basic method followed was that of the guided field-walk as described by Martin (10) and Maundu (11). Information was obtained from the healers during field-walks where the informant pointed out plant species and described their medicinal as well as any other uses. Information was obtained on the plant parts used, formulations, dosages, side-effects if any and when appropriate, whether the plant species was included in the diet for preventive or curative properties. At the request of the Chakma healers, formulations, dosage and side-effects data are not included in the paper for they requested confidentiality on these data on grounds that dissemination of these data would be detrimental to their professional practices. The healers, however, had no objections to publishing the data on medicinal plant species, their medicinal uses and whether they are used as functional foods, i.e. food supplements. Agreement was reached that any financial benefit accruing from the publication would be handed over to the healers to be spent for the general welfare of the communities.

Plant specimens were photographed as well as collected, pressed and dried in the field. Plant specimens were identified by Mr. Manzur-ul Kadir Miah (plant taxonomist at the Bangladesh National Herbarium, since retired).

\section{Results and Discussion}

Plants, their distribution into families, plant parts used and mode of application

The results of showed that 55 species of plants are used by the traditional healers of the Chakma tribe in Bandarban district, Bangladesh. These medicinal plants belong to 37 families (Table 1). The major families included Acanthaceae, Apocynaceae, Asteraceae/Compositae, Euphorbiaceae, and Fabaceae. Leaves were the most commonly used part followed by roots, barks and fruits. The mode of application was either oral or topical. In the majority of cases juice extracted from whole plant or plant part (through crushing) was either taken orally or topically applied to affected areas. This applied to cases like tonsillitis, where plant sap from Alstonia scholaris was massaged externally around the tonsils.

Table 1: Medicinal plant used by the Chakma healers at the Chakma settlements of Gundum, Naikhongchhari and Tombru of Bandarban district, Bangladesh

\begin{tabular}{|c|c|c|c|c|}
\hline Botanical name & Family & Local name & Parts used & Ailments treated/Uses (Administration) \\
\hline $\begin{array}{l}\text { Acanthus illicifolius } \\
\text { L. }\end{array}$ & Acanthaceae & View-kada & Root & Aphrodisiac, joint pain, swelling $(\mathrm{O})$. \\
\hline Justicia adhatoda L. & Acanthaceae & Bashok & Leaf & $\begin{array}{l}\text { Asthma, coughs, mucus, pneumonia in children } \\
(\mathrm{O}) \text {. }\end{array}$ \\
\hline $\begin{array}{l}\text { Justicia gendarussa } \\
\text { L. }\end{array}$ & Acanthaceae & Chaw-mukha gach & Leaf & Abscess within the nostrils (T). \\
\hline \begin{tabular}{|l} 
Sansevieria \\
roxburghiana \\
Schult. \& Schult.f.
\end{tabular} & Agavaceae & Kanfada, Kanchidi & $\begin{array}{c}\text { Leaf, } \\
\text { meristem }\end{array}$ & $\begin{array}{l}\text { Ear infections, pus formation in ears, bursting } \\
\text { of eardrums }(\mathrm{T}) \text {. }\end{array}$ \\
\hline $\begin{array}{l}\text { Achyranthes aspera } \\
\text { L. }\end{array}$ & Amaranthaceae & Sesaika, Apang & Root & Jaundice, asthma $(\mathrm{O})$. \\
\hline $\begin{array}{l}\text { Lannea } \\
\text { coromandelica } \\
\text { (Houtt.) Merr. }\end{array}$ & Anacardiaceae & Paharibadi & Bark & Dysentery, blood dysentery, diarrhea $(\mathrm{O})$. \\
\hline $\begin{array}{l}\text { Mangifera longipes } \\
\text { Griff. }\end{array}$ & Anacardiaceae & Uri-aam & Bark, fruit & $\begin{array}{l}\text { Chronic leucorrhea, dysentery, blood dysentery } \\
\text { (O). Bark is used as curative, but fruits are } \\
\text { edible and consumed when in season. }\end{array}$ \\
\hline $\begin{array}{l}\text { Alstonia scholaris } \\
\text { (L.) R.Br. }\end{array}$ & Apocynaceae & Sytton gach & $\begin{array}{l}\text { Bark, plant } \\
\quad \text { sap }\end{array}$ & $\begin{array}{l}\text { Tonsillitis, muscle pain, abscess (plant sap, T), } \\
\text { kala azar (plant sap, O), low semen density, } \\
\text { fever (bark, O). }\end{array}$ \\
\hline \begin{tabular}{|l} 
Holarrhena \\
pubescens Wall. ex \\
G. Don
\end{tabular} & Apocynaceae & Koruj gach & Bark & Leucorrhea, bloating, diarrhea $(\mathrm{O})$. \\
\hline
\end{tabular}




\begin{tabular}{|c|c|c|c|c|}
\hline Botanical name & Family & Local name & Parts used & Ailments treated/Uses (Administration) \\
\hline $\begin{array}{l}\text { Tabernaemontana } \\
\text { divaricata }(\mathrm{L} .) \text { R. } \\
\text { Br. ex Roemer \& } \\
\text { J.A. Schultes } \\
\end{array}$ & Apocynaceae & Kathyamali & Root & $\begin{array}{l}\text { Long-time coughs, phlegm, lung tonic, oral } \\
\text { lesions, fever with convulsions }(\mathrm{O}) \text {. }\end{array}$ \\
\hline $\begin{array}{l}\text { Calotropis gigantea } \\
\text { (L.) Ait.f. }\end{array}$ & Asclepiadaceae & Or gach & Leaf & Body pain (T). \\
\hline Blumea lacera $\mathrm{DC}$ & $\begin{array}{c}\text { Asteraceae/Compo } \\
\text { sitae }\end{array}$ & Kuid-muta & Meristem & Severe eczema $(\mathrm{T})$. \\
\hline Eclipta erecta $\mathrm{L}$. & $\begin{array}{c}\text { Asteraceae/Compo } \\
\text { sitae }\end{array}$ & $\begin{array}{l}\text { Kala-hona, kala- } \\
\text { manik }\end{array}$ & Whole plant & $\begin{array}{l}\text { To keep head cool, hair loss, blackening of hair } \\
\text { (T). }\end{array}$ \\
\hline $\begin{array}{l}\text { Elephantopus } \\
\text { scaber L. }\end{array}$ & $\begin{array}{c}\text { Asteraceae/Compo } \\
\text { sitae }\end{array}$ & Mul-gach, Ak-foilla & Root & $\begin{array}{l}\text { Low semen density, leukoderma, burning } \\
\text { sensations in the body, severe leucorrhea, } \\
\text { irregular urination, urinary pressure but } \\
\text { passage of low quantities of urine }(\mathrm{O}) \text {. }\end{array}$ \\
\hline $\begin{array}{l}\text { Mikania cordata } \\
\text { (Burm. F.) B. L. } \\
\text { Robinson }\end{array}$ & $\begin{array}{l}\text { Asteraceae/Compo } \\
\text { sitae }\end{array}$ & $\begin{array}{c}\text { Jarmani lota, Japani } \\
\text { lota }\end{array}$ & Leaf & $\begin{array}{l}\text { Scabies, infections }(\mathrm{T}) \text {, severe diarrhea, } \\
\text { astringent }(\mathrm{O}) \text {. }\end{array}$ \\
\hline $\begin{array}{l}\text { Heterophragma } \\
\text { adenophyllum } \\
\text { Seem. }\end{array}$ & Bignoniaceae & Kau-a-turi & Root & Piles, constipation $(\mathrm{O})$. \\
\hline $\begin{array}{l}\text { Oroxylum indicum } \\
\text { (L.) Vent. }\end{array}$ & Bignoniaceae & Chilana gach & Fruit, bark & $\begin{array}{l}\text { Pus with urine, burning sensations in urinary } \\
\text { tract, pus with semen (fruit, O), scabies (bark, } \\
\text { T). }\end{array}$ \\
\hline $\begin{array}{l}\text { Bombax } \\
\text { pentandrum } \mathrm{L} .\end{array}$ & Bombacaceae & Tula & $\begin{array}{c}\text { Root from } \\
\text { one year old } \\
\text { plants }\end{array}$ & Low semen density, erectile dysfunction $(\mathrm{O})$. \\
\hline \begin{tabular}{|l|} 
Casuarinas \\
equisetifolia $\mathrm{L}$. \\
\end{tabular} & Casuarinaceae & Jhau gach & Bark & $\begin{array}{l}\text { Strengthening of gums, remove foul odor from } \\
\text { mouth (bark is chewed and spitted out). }\end{array}$ \\
\hline $\begin{array}{l}\text { Terminalia arjuna } \\
\text { (Roxb. ex DC.) } \\
\text { Wight \& Arn. } \\
\end{array}$ & Combretaceae & Arjun & Bark & $\begin{array}{l}\text { Abnormal heart palpitations, diarrhea, } \\
\text { dysentery, blood dysentery, kala azar, } \\
\text { abnormal heart palpitations, vertigo }(\mathrm{O}) \text {. }\end{array}$ \\
\hline $\begin{array}{l}\text { Terminalia chebula } \\
\text { Retz. }\end{array}$ & Combretaceae & Hortoki & Fruit & $\begin{array}{l}\text { Sedative, respiratory problems, allergy }(\mathrm{O}) \text {. } \\
\text { Used as both preventive and curative. }\end{array}$ \\
\hline $\begin{array}{l}\text { Costus speciosus (J. } \\
\text { König.) Sm. }\end{array}$ & Costaceae & Tiatui & Root & Jaundice, to clarify urine, kidney stones (O). \\
\hline $\begin{array}{l}\text { Coccinia grandis } \\
\text { (L.) J. Voigt }\end{array}$ & Cucurbitaceae & Telpuchi & $\begin{array}{r}\text { Vine (leaf } \\
\text { with stem) }\end{array}$ & $\begin{array}{l}\text { Diabetes, burning sensations in urinary tract } \\
(\mathrm{O}) \text {. Used as both preventive and curative. }\end{array}$ \\
\hline $\begin{array}{l}\text { Hodgsonia } \\
\text { macrocarpa Cogn. }\end{array}$ & Cucurbitaceae & $\begin{array}{c}\text { Kaida phol, Makal } \\
\text { phol }\end{array}$ & $\begin{array}{c}\begin{array}{c}\text { Fruit, skin of } \\
\text { fruit }\end{array} \\
\end{array}$ & $\begin{array}{l}\text { Stomach ache in children (fruit, O), white } \\
\text { patches on skin of children (skin of fruit, T). }\end{array}$ \\
\hline $\begin{array}{l}\text { Cuscuta reflexa } \\
\text { Roxb. }\end{array}$ & Cuscutaceae & Swarna lata & Vine & Astringent, malaria $(\mathrm{O})$. \\
\hline $\begin{array}{l}\text { Gelonium } \\
\text { multiflorum A. Juss. }\end{array}$ & Euphorbiaceae & \begin{tabular}{l|l} 
Chagol ladi & 8
\end{tabular} & Leaf & Diabetes $(\mathrm{O})$. \\
\hline $\begin{array}{l}\text { Phyllanthus } \\
\text { reticulatus Poir. }\end{array}$ & Euphorbiaceae & Dath-bohori & Stem & $\begin{array}{l}\text { To strengthen gums (stem is chewed and } \\
\text { spitted out). }\end{array}$ \\
\hline $\begin{array}{l}\text { Premna esculenta } \\
\text { Roxb. }\end{array}$ & Euphorbiaceae & Lelom pata & Root & Diabetes $(\mathrm{O})$, animal bites $(\mathrm{T})$. \\
\hline Cassia alata $\mathrm{L}$. & Fabaceae & Daud gach & Leaf & Helminthiasis $(\mathrm{O})$. \\
\hline Cassia fistula L. & Fabaceae & Unalu, Banor lathi & Fruit, bark & $\begin{array}{l}\text { Loss of appetite, fever (fruit, O), helminthiasis } \\
(\text { bark, O). }\end{array}$ \\
\hline Cassia tora $\mathrm{L}$. & Fabaceae & Tankai & $\begin{array}{l}\text { Leaf with } \\
\text { root, seed }\end{array}$ & $\begin{array}{l}\text { Fever, pre-fever symptoms, pain, tiredness } \\
\text { (leaf with root, O), allergy, scabies, itches } \\
\text { (seed, T). }\end{array}$ \\
\hline Clitoria ternatea $\mathrm{L}$. & Fabaceae & Omaio & $\begin{array}{l}\text { Leaf with } \\
\text { stem }\end{array}$ & $\begin{array}{l}\text { Itches and development of black spots due to } \\
\text { itches in children }(\mathrm{T}) \text {. }\end{array}$ \\
\hline $\begin{array}{l}\text { Hyptis suaveolens } \\
\text { (L.) Poit. }\end{array}$ & Lamiaceae & Tokma & Fruit, seed & $\begin{array}{l}\text { To maintain efficient heart functioning, heart } \\
\text { palpitations, laxative }(\mathrm{O}) \text {. Used as both } \\
\text { preventive and curative. }\end{array}$ \\
\hline $\begin{array}{l}\text { Dehaasia kurzii } \\
\text { King ex Hook.f. }\end{array}$ & Lauraceae & $\begin{array}{l}\text { Mojar mostapata, } \\
\text { Modon-bocchu }\end{array}$ & Leaf with root & Aphrodisiac, impotency (O). \\
\hline $\begin{array}{l}\text { Lygodium } \\
\text { flexuosum (L.) Sw. }\end{array}$ & Lygodiaceae & Roge-poti & Vine & Jaundice, fever (O). \\
\hline
\end{tabular}




\begin{tabular}{|c|c|c|c|c|}
\hline Botanical name & Family & Local name & Parts used & Ailments treated/Uses (Administration) \\
\hline Lawsonia inermis L. & Lythraceae & Mehedi & Leaf & $\begin{array}{l}\text { Severe headache }(\mathrm{O}) \text {, to keep head cool }(\mathrm{T}) \text {, } \\
\text { aphrodisiac, chronic dysentery }(\mathrm{O}) \text {. }\end{array}$ \\
\hline Urena lobata L. & Malvaceae & $\begin{array}{l}\text { Bulbuli gach, } \\
\text { Kuidda gach }\end{array}$ & Leaf & $\begin{array}{l}\text { Pus with semen, burning sensations in urinary } \\
\text { tract, lower abdominal pain, pressure for } \\
\text { urination but passage of only a few drops of } \\
\text { urine, urinary tract infections }(\mathrm{O}) \text {. }\end{array}$ \\
\hline $\begin{array}{l}\text { Melastoma } \\
\text { malabathricum } \mathrm{L} .\end{array}$ & Melastomataceae & Putti gach & Root & Jaundice $(\mathrm{O})$ \\
\hline $\begin{array}{l}\text { Azadirachta indica } \\
\text { A. Juss. }\end{array}$ & Meliaceae & Neem & Leaf, stem & $\begin{array}{l}\text { Bloating, vomiting (leaf, O), scabies, eczema, } \\
\text { skin diseases (leaf, T), strengthening of gums } \\
\text { (stem is chewed and spitted out). }\end{array}$ \\
\hline $\begin{array}{l}\text { Swietenia } \\
\text { macrophylla King. }\end{array}$ & Meliaceae & Mehegoni & Seed & Diabetes $(\mathrm{O})$ \\
\hline $\begin{array}{l}\text { Stephania japonica } \\
\text { (Thunb.) Miers }\end{array}$ & Menispermaceae & Muicchani lota & Leaf & $\begin{array}{l}\text { Low semen density, burning sensations during } \\
\text { urination, urine coming out in several streams } \\
\text { (O). }\end{array}$ \\
\hline Streblus asper Lour. & Moraceae & Aurga & $\begin{array}{l}\text { Leaf with } \\
\text { stem }\end{array}$ & $\begin{array}{l}\text { Syphilis, passage of blood or blood clots with } \\
\text { urine, low semen density, aphrodisiac }(\mathrm{O}) \text {. }\end{array}$ \\
\hline $\begin{array}{l}\text { Syzygium cumini } \\
\text { (L.) Skeels }\end{array}$ & Myrtaceae & Kali-jaam & Seed, fruit & $\begin{array}{l}\text { Diabetes, urinary problems, relaxant. Used as } \\
\text { both preventive and curative. }\end{array}$ \\
\hline $\begin{array}{l}\text { Nymphaea nouchali } \\
\text { Burm.f. }\end{array}$ & Nymphaeaceae & Lal shapla & Root & $\begin{array}{l}\text { Reduces heavy excess menstrual bleeding }(\mathrm{O}) \text {. } \\
\text { Used as curative, but also taken as vegetable. }\end{array}$ \\
\hline $\begin{array}{l}\text { Andropogon } \\
\text { acicularis Willd. }\end{array}$ & Poaceae & Naanochi & Soft root & Animal bites $(\mathrm{T})$. \\
\hline $\begin{array}{l}\text { Polygonum } \\
\text { hydropiper } \mathrm{L} .\end{array}$ & Polygonaceae & Bish-kadali & Leaf & Helminthiasis, bloating $(\mathrm{O})$. \\
\hline $\begin{array}{l}\text { Drynaria } \\
\text { quercifolia (L.) J. } \\
\text { Smith }\end{array}$ & Polypodiaceae & Gundirmul & Root & Gonorrhea, frequent urination $(\mathrm{O})$. \\
\hline $\begin{array}{l}\text { Acrostichum } \\
\text { aureum L. }\end{array}$ & Pteridaceae & Moun shak & $\begin{array}{l}\text { Leaf with } \\
\text { stem }\end{array}$ & $\begin{array}{l}\text { Low semen density, impotency, leucorrhea }(\mathrm{O}, \\
\text { cooked and eaten as vegetable). }\end{array}$ \\
\hline $\begin{array}{l}\text { Zizyphus oenoplia } \\
\text { (L.) Mill. }\end{array}$ & Rhamnaceae & Pahari boroi & Root & Dysentery $(\mathrm{O})$ \\
\hline $\begin{array}{l}\text { Aegle marmelos (L.) } \\
\text { Corr. }\end{array}$ & Rutaceae & Cip-bael & Fruit & $\begin{array}{l}\text { Dysentery, blood dysentery, chronic leucorrhea } \\
\text { (O). Used as both preventive and curative. }\end{array}$ \\
\hline Datura metel L. & Solanaceae & Dhutura & Seed & Rheumatic pain (T). \\
\hline $\begin{array}{l}\text { Pterospermum } \\
\text { semisagittatum } \\
\text { Blanco }\end{array}$ & Sterculiaceae & Lanachar gach & $\begin{array}{l}\text { Root with } \\
\text { bark }\end{array}$ & Blood dysentery, mental instability, piles $(\mathrm{O})$. \\
\hline $\begin{array}{l}\text { Clerodendrum } \\
\text { viscosum Vent }\end{array}$ & Verbenaceae & Choit ghata & Leaf with root & $\begin{array}{l}\text { Sudden stomach pain, gastric problems, fever, } \\
\text { loss of appetite, digestive aid }(\mathrm{O}) \text {. }\end{array}$ \\
\hline Vitex negundo L. & Verbenaceae & Miunda gach & Leaf & $\begin{array}{l}\text { Pain and blood during and after urination, } \\
\text { allergy }(\mathrm{O}) \text {, scabies }(\mathrm{T}) \text {. }\end{array}$ \\
\hline $\begin{array}{l}\text { Alpinia nigra } \\
\text { (Gaertn.) B. L. } \\
\text { Burtt. }\end{array}$ & Zingiberaceae & Khet-tara & Root & Paralysis $(\mathrm{O})$ \\
\hline
\end{tabular}

Plants which can be used as food supplements are indicated in bold lettering. O stands for oral administration and $\mathrm{T}$ stands for topical application of the indicated plant part. Unless otherwise mentioned (like chewing followed by spitting), juice collected from the indicated plant part(s) were orally administered or topically applied. Also note that one plant (Acrostichum aureum) was cooked and eaten as vegetable only during the duration of the sickness and so has not been considered as food supplement.

\section{Medical applications}

It was observed that single plant was used by Chakma traditional healers for treatment of a single ailment or diverse ailments. Combination of plants was not observed. Apart from Calotropis gigantea, Blumea lacera, Gelonium multiflorum, Cassia alata, Melastoma malabathricum, Swietenia macrophylla, Andropogon acicularis, Zizyphus oenoplia, Datura metel and Alpinia nigra, 
which were used to treat a single ailment, the other 45 plants were utilized to treat multiple ailments. Occasionally, different parts from the same plant may be used to treat different ailments. For instance, sap of Alstonia scholaris was used for treating tonsillitis, muscle pain, abscess pain, and kala azar, while bark of the plant was used to treat low semen density, and fever. The leaves of Azadirachta indica were used to treat bloating, vomiting, scabies, eczema and other skin diseases, while the stem was used for strengthening of gums. The same plant part may be used for both oral and topical applications. Leaf juice of Azadirachta indica was administered orally for treatment of bloating or vomiting, but used topically for scabies, eczema and other skin diseases. Although the present survey did not find usage by Chakma traditional healers of combination of different plants to treat ailments, combination of plant parts from the same plant was found to be used quite frequently. To cite only two examples, the leaves and roots of Dehaasia kurzii were used in combination to treat impotency and as an aphrodisiac. The leaves and stems of Acrostichum aureum were used in combination to treat low semen density, impotency, and leucorrhea. The surveyed data suggests that respiratory tract disorders, gastrointestinal tract disorders, skin disorders, urinary tract disorders, helminthiasis and diabetes are quite common amongst the Chakmas. Kala azar, a chronic and potentially fatal disease (also known as leishmaniasis) is also present within the Chakmas and treated with a number of plants like Alstonia scholaris or Terminalia arjuna. Malaria, which is another potentially fatal disease, is treated with vines of Cuscuta reflexa.

Plants used by the Chakma tribe which can serve as food supplements.

A total of seven plants were found to be consumed by the Chakma tribe or administered by tribal healers and which can serve as food supplements. These plants belonged to seven families (Table 1). Fruits formed the major part of the plant that was consumed. The various ailments for which plant or plant parts were used for preventive or curative purposes included gastrointestinal disorders, urinary tract disorders, heart problems, and respiratory problems. Both our published and unpublished observations as shown in Table 2 indicated that the seven plants or plant parts are used by other tribes or in other regions of Bangladesh to treat a wide variety of ailments, as a preventive measure against several ailments, as well as to maintain good health.

Table 2: Uses of "food supplement" plants in Table 1 by other tribes or in other regions of Bangladesh*

\begin{tabular}{|c|c|c|}
\hline Botanical name & Ailments/Uses & Comments \\
\hline Aegle marmelos (L.) Corr. & $\begin{array}{l}\text { Indigestion, piles, constipation, respiratory } \\
\text { problems, inflammation, insect or snake bites, heart } \\
\text { palpitations, fever, clearing of bowels, to keep } \\
\text { body cool, diarrhea, dysentery, diabetes (12, 13, } \\
\text { 14); leucorrhea, sex stimulant, inflammation, } \\
\text { diabetes, peptic ulcer, sedative, colic, appetizer, } \\
\text { snake bite, laxative, flatulence, malaria, soothing of } \\
\text { the body, insect bite, ear infection, eye disease, } \\
\text { jaundice, gonorrhea, cancer, hepatic disorders, } \\
\text { tuberculosis, asthma, coughs, to increase sperm } \\
\text { count, influenza, pain, paralysis, piles, vomiting } \\
\text { tendency (unpublished observations). }\end{array}$ & $\begin{array}{l}\text { Plant parts used include whole plant, leaf, root, bark, } \\
\text { flower, fruit (both unripe and ripe), and seed. The fruit } \\
\text { is edible and both unripe and ripe fruits are eaten on a } \\
\text { regular basis. Fruits are considered as serving both } \\
\text { preventive and curative purposes in gastrointestinal } \\
\text { disorders like stomachache, indigestion, diarrhea, and } \\
\text { dysentery. Some traditional healers consider the pulp } \\
\text { of the ripe fruit as having hypoglycemic properties. }\end{array}$ \\
\hline Coccinia grandis (L.) J. Voigt & $\begin{array}{l}\text { Diarrhea, blood dysentery, dizziness from } \\
\text { sunstroke, dysentery, leucorrhea, menstrual } \\
\text { problems, diabetes }(13,15) \text {; edema, eye diseases, } \\
\text { bloating, hypertension, inflammation, coughs, } \\
\text { jaundice, mental diseases, lung disorders, } \\
\text { dermatitis, typhoid, burning sensations in hands or } \\
\text { feet, to induce vomiting, bed-wetting in children } \\
\text { (unpublished observations). }\end{array}$ & $\begin{array}{l}\text { Plant parts used include whole plant, leaf, stem, root, } \\
\text { and flower. The leaf is frequently consumed or raw } \\
\text { leaf juice taken to keep blood sugar under control } \\
\text { during diabetes. The leaves and stems of the plant are } \\
\text { also cooked and eaten as vegetable. }\end{array}$ \\
\hline Hyptis suaveolens (L.) Poit. & $\begin{array}{l}\text { Liver diseases, cancer, constipation, insect } \\
\text { repellent, expectorant, cuts and wounds (to stop } \\
\text { bleeding), malaria, indigestion, headache, } \\
\text { rheumatoid arthritis, laxative, gonorrhea, diabetes, } \\
\text { dermatitis, lack of appetite (unpublished } \\
\text { observations). }\end{array}$ & $\begin{array}{l}\text { Plant parts used include leaf, bark, root, fruit, seed, } \\
\text { and whole plant. Seeds are considered throughout the } \\
\text { country as having laxative effects. They are soaked } \\
\text { overnight in water and taken the following morning to } \\
\text { get relief from constipation. It also has a soothing } \\
\text { effect on the stomach. Soaked seeds are also taken as } \\
\text { preventive medicine for flatulency. }\end{array}$ \\
\hline
\end{tabular}




\begin{tabular}{|c|c|c|}
\hline Botanical name & Ailments/Uses & Comments \\
\hline Mangifera longipes Griff. & $\begin{array}{l}\text { None reported in the ethnobotanical surveys except } \\
\text { for its use by the Chakma tribe. }\end{array}$ & $\begin{array}{l}\text { Fruits are edible and consumed when seasonally } \\
\text { available. Mangifera longipesis not available in } \\
\text { Bangladesh apart from the Chittagong Hill Tracts } \\
\text { region. In the rest of the country, the more common } \\
\text { species is Mangifera indica. }\end{array}$ \\
\hline Nymphaea nouchali Burm.f. & $\begin{array}{l}\text { Burning sensations in urinary tract, leucorrhea (14); } \\
\text { indigestion, heart diseases, cuts and wounds (to } \\
\text { stop bleeding), stomachache, diarrhea, diabetes } \\
\text { (unpublished observations). }\end{array}$ & $\begin{array}{l}\text { Plant parts used include whole plant, stem, root tops, } \\
\text { and flower. The plant is edible and is eaten as } \\
\text { vegetable, particularly by the rural population of the } \\
\text { country. }\end{array}$ \\
\hline Syzygium cumini (L.) Skeels & $\begin{array}{l}\text { Inflammation, infrequent urination, burning } \\
\text { sensations in urinary tract, fever, gastrointestinal } \\
\text { problems, diarrhea, blood with stool, toothache, } \\
\text { skin disorders, diabetes }(12,15) \text {; constipation, } \\
\text { dermatitis, toothache, skin disorders, sex stimulant, } \\
\text { anemia, wounds, eczema, hepatitis, piles, } \\
\text { rheumatoid arthritis, tooth infections, liver } \\
\text { dysfunction, short-sightedness, allergy } \\
\text { (unpublished observations). }\end{array}$ & $\begin{array}{l}\text { Plant parts used include leaf, bark, fruit, seed and seed } \\
\text { kernel. The fruit is edible and enjoys consumer } \\
\text { demand. Fruit, besides being nutritive, is also } \\
\text { considered to lower blood sugar level during diabetes. } \\
\text { Crushed seeds are taken as preventive measure every } \\
\text { morning to control blood sugar. }\end{array}$ \\
\hline Terminalia chebula Retz. & $\begin{array}{l}\text { Appetite stimulant, aids digestion, acidity, } \\
\text { stomachic }(13,16) \text {; asthma, cardiovascular } \\
\text { disorders, eye diseases, itches, night blindness, } \\
\text { cancer, jaundice, bronchitis, leucorrhea, tumor, } \\
\text { tuberculosis, ulcer, burns, low sperm count, urinary } \\
\text { troubles, coughs, bloating, biliary problems, acne, } \\
\text { helminthiasis, hepatic disorders, leprosy, malaria, } \\
\text { hepatitis, debility, abscess pain, fever, to blacken } \\
\text { hair (unpublished observations). }\end{array}$ & $\begin{array}{l}\text { Plants parts used include leaf, bark, fruit, seed, and } \\
\text { whole young plants. The fruit is edible and considered } \\
\text { to provide protection against diverse ailments and } \\
\text { disorders as well as to maintain good health. Fresh } \\
\text { fruits are consumed when available; during off } \\
\text { season, dried fruits are consumed. }\end{array}$ \\
\hline
\end{tabular}

* It is to be noted that some of the uses of plants have been published (References 12-16), and others have been unpublished. These observations form a part of our on-going ethnobotanical surveys of various tribes and regions in Bangladesh.

\section{Pharmacological and nutritive evaluation of plants}

Aegle marmelos is traditionally used in India to cure diarrhea, intestinal disorders, fever, scurvy, coughs, cold and diabetes. Methanolic extracts of plant parts like leaves, bark, fruit rind and fruit pulp have demonstrated the presence of carbohydrates, proteins, amino acids, anthocyanins, sterols, flavonoids and glycosides. The various plant parts also demonstrated significant antioxidant activities (17), which can have both preventive and curative effects in a number of ailments like cardiovascular disorders, inflammation, and respiratory tract disorders. In another study on the antioxidant effects of bark of this plant, it was observed that an aqueous-alcoholic extract showed high nitric oxide (NO) quenching potential, which correlated with presence of phenolic compounds and tannins in the bark (18). The seed oil of the plant reportedly possesses compounds with antimicrobial activity (19), and the fruit has been shown to have potential in vitro to combat oxidative stress $(20)$.

Coccinia grandis is used by the indigenous peoples of India to treat gout and hepatic disorders. A study with the methanol extract of the plant found significantly decreased serum urate levels when compared to hyperuricaemic controls along with significant inhibition of xanthine oxidase activity in mice (21). Ethanol extract of the plant reportedly demonstrated significant triglyceride and cholesterol lowering effects in dyslipidemic hamster model, which has been attributed to a C-60 polyphenol present in the plant (22). Methanolic extract of the fruits and leaves have been shown to demonstrate hepatoprotective activity against carbon tetrachloride-induced hepatic injury in rats $(23,24)$. Hydromethanolic extract of the leaves has been reported to possess free radical scavenging and antioxidant activities, which has been attributed to presence of phenolic and flavonoid compounds in leaves (25). The hypocholesterolemic and antioxidant activity justify prophylactic use of the plant by the Chakmas in diabetes.

The essential oil from whole plant or plant parts of Hyptis suaveolens contain numerous pharmacologically active compounds, among which are $\beta$-caryophyllene, $\alpha$-phellandrene, 
caryophyllene oxide (26), sabinene, 1,8-cineole, $\gamma$-terpinene, fenchone, and fenchol (27). $\beta$ Caryophyllene is known to exert negative inotropic effects in heart muscle (28) validating its use by the Chakmas for heart palpitations or arrhythmias. The plant contains a high percentage of crude alkaloids and flavonoids (29). The percentage of crude protein in seeds, leaves, and stems has been shown to be 14.7, 11.38, and 6.56\%, respectively (30). Although Mangifera longipes (used by the Chakmas as treatment for chronic leucorrhea and gastrointestinal disorders like dysentery and blood dysentery) has not been studied, methanolic extracts of seeds of a related species Mangifera indica have been reported to possess anti-diarrheal activity (31). The aqueous decoction of flowers of the plant has also been reported to act as an anti-ulcer agent in mice and rats (32).

The fruits of Syzygium cumini (used by the Chakmas to treat diabetes) contain antioxidant tannins (33). Leaf extracts also contain antioxidant activity, which has been attributed to the presence of phenolic compounds like ferulic acid and catechin (34). Ferulic acid, which is also present in seeds of this plant, has been implicated in amelioration of diabetes due to its pancreatic $\beta$-cell regenerative effect and/or due to its antioxidant properties (35). The seeds are rich in flavonoid compounds, which reportedly demonstrated both hypoglycemic and hypolipidemic effects in streptozotocin-induced diabetic rats (36). Seed kernels have been reported to possess $\alpha$-glucosidase inhibitory activity in vitro and in Goto-Kakazaki (GK) rats and could be a mechanism by which this plant exerts its antidiabetic potential (37). Ethanolic extract of seeds showed presence of novel androstane derivatives and reduced elevated blood glucose levels in alloxan-induced diabetes in rats (38). Fruit pulp is rich in carbohydrates, proteins and minerals (especially calcium), phenols, anthocyanins and flavonoids and demonstrated in vitro antioxidant activities (39). The seeds have been found to be rich in elements like zinc, chromium, vanadium, potassium, and sodium - all elements being considered to play an important role in contributing to hypoglycemic activity (40). Alcoholic extract of seeds has been found to contain strong antioxidant compounds like gallic acid, ellagic acid, corilagin and related ellagitannins, 1-galloyl glucose, 3-galloyl glucose, and quercetin (41). Taken together, the reported chemical profile of fruits and seeds of Syzygium cumini suggest presence of compounds with strong antioxidant properties, which if consumed on a regular basis can be a preventive measure against a diverse variety of diseases.

The edible fruits of Terminalia chebula (used by the Chakmas to combat respiratory problems and allergy) reportedly contain 10.3 and 14.5 times more vitamin $\mathrm{C}$ and protein, respectively, when compared to apples. The minimum recommended dietary allowances for micronutrients like Se, $\mathrm{K}$, $\mathrm{Mn}, \mathrm{Fe}$ and $\mathrm{Cu}$ can be met if $100 \mathrm{~g}$ of the raw fruit is eaten (42). The plant can thus be of potential nutritive value, while antioxidant like vitamin $\mathrm{C}$ present in the plant can be of aid in alleviating respiratory problems. Strong polyphenolic antioxidants like ellagic and gallic acid have also been reported in this plant (43). In Thailand, the plant reportedly is sued to treat diabetes in the traditional medicinal system. Strong antioxidant activity has been confirmed in the plant (44). In traditional Indian medicine, the plant is used for strengthening the body immune system as well forming a rich source of essential nutrient elements; the fruits are especially enriched in magnesium (45). The immunomodulatory activities of the plant have been confirmed in studies on neutrophil functions (46). The aqueous extract of the fruits has also been confirmed to have strong antioxidant properties $(47,48)$ and has been postulated to play a role in the hepatic prevention of oxidative damage in living systems (48). Taken together, it appears from the available studies that fruits of Terminalia chebula are a good source of macro- as well as micronutrients, besides possessing components with strong antioxidant activities. Considering also the reported immune-stimulating activity, the plant can play an important role both in prevention of ailments as well alleviating infective diseases.

Overall, a pharmacological and nutritive evaluation of plants used by the Chakma tribe indicates that the seven plants (or plant parts) reported in the present study has good potential both as food supplements and be of use medicinally. Thus they can play the role of functional foods. Various plant parts like fruits, seeds and stems are edible and are eaten on a regular basis by the tribal people when 
in season without any known ill effects. Since modern medical facilities are out of reach from a substantial section of the population of the country, regular use of the above plants by the general population as food supplements can serve both preventive and curative purposes. This should also reduce the cost of health care, which a majority of the population can ill afford with incomes at or below 1 US\$ per day. The present study is expected to generate enough interest towards more effective conservation, cultivation and consumption of the seven plants described in the study.

\section{References}

1. Anderson, J.W. and Gustafson, N.J. (1988). Hypocholesterolemic effects of oat and bean products. Am. J. Clin. Nutr. 48(3 Suppl): 749-753.

2. Dorant, E., van den Brandt, P.A., Goldbohm, R.A. and Sturmans, F. (1996). Consumption of onions and a reduced risk of stomach carcinoma. Gastroenterology, 110(1): 12-20.

3. Dvorkin, L. and Song, K.Y. (2002). Herbs for benign prostatic hyperplasia. Ann. Pharmacother., 36(9): 1443-1452.

4. Yeh, G.Y., Eisenberg, D.M., Kaptchuk, T.J. and Phillips, R.S. (2003). Systematic review of herbs and dietary supplements for glycemic control in diabetes. Diabetes Care, 26(4): 1277-1294.

5. Makonnen, E., Debella, A., Zerihun, L., Abebe, D. and Teka, F. (2003). Antipyretic properties of the aqueous and ethanol extracts of the leaves of Ocimum suave and Ocimum lamiifolium in mice. J. Ethnopharmacol. 88(1): 85-91.

6. Yu, S.M., Ghandour, R.M. and Huang, Z.J. (2004). Herbal supplement use among US women, 2000. J. Am. Med. Womens Assoc. 59(1): 17-24.

7. Valentová, K. and Ulrichová, J. (2003). Smallanthus sonchifolius and Lepidium meyenii - prospective Andean crops for the prevention of chronic diseases. Biomed. Pap. Med. Fac. Univ. Palacky Olomouc Czech Repub. 147(2): 119-130.

8. Esiyok, D., Otles, S. and Akcicek, E. (2004). Herbs as a food source in Turkey. Asian Pac. J. Cancer Prev. 5(3): 334 339.

9. Kim, J.H., Hong, J.Y., Shin, S.R. and Yoon, K.Y. (2009). Comparison of antioxidant activity in wild plant (Adenophora triphylla) leaves and roots as a potential source of functional foods. Int. J. Food Sci. Nutr. 60 Suppl 2: 150-161.

10. Martin, G.J. (1995). Ethnobotany: a 'People and Plants' Conservation Manual. Chapman and Hall, London. 268 pp.

11. Maundu, P. (1995). Methodology for collecting and sharing indigenous knowledge: a case study. Indigenous Knowledge and Development Monitor, 3: 3-5.

12. Hanif, A., Hossan, M.S., Mia, M.M.K., Islam, M.J., Jahan, R. and Rahmatullah, M. (2009). Ethnobotanical survey of the Rakhain tribe inhabiting the Chittagong Hill Tracts region of Bangladesh. Am.-Eurasian J. Sustain. Agric. 3(2): 172-180.

13. Nawaz, A.H.M.M., Hossain, M., Karim, M., Khan, M., Jahan, R. and Rahmatullah, M. (2009). An ethnobotanical survey of Rajshahi district in Rajshahi division, Bangladesh. Am.-Eurasian J. Sustain. Agric. 3(2): 143-150.

14. Hossan, M.S., Hanif, A., Khan, M., Bari, S., Jahan, R. and Rahmatullah, M. (2009). Ethnobotanical survey of the Tripura tribe of Bangladesh. Am.-Eurasian J. Sustain. Agric. 3(2): 253-261.

15. Nawaz, A.H.M.M., Hossain, M., Karim, M., Khan, M., Jahan, R. and Rahmatullah, M. (2009). An ethnobotanical survey of Jessore district in Khulna division, Bangladesh. Am.-Eurasian J. Sustain. Agric. 3(2): 195-201.

16. Mia, M.M.M., Kadir, M.F., Hossan, M.S. and Rahmatullah, M. (2009). Medicinal plants of the Garo tribe inhabiting the Madhupur forest region of Bangladesh. Am.-Eurasian J. Sustain. Agric. 3(2): 165-171.

17. Surekha, K. and Sambare, S. (2006). Phytochemical analysis of Aegle marmelos L. (Corr.) in relation to its antioxidant activity. Indian J. Appl. Pure Biol. 21(2): 207-210.

18. Kumari, A. and Kakkar, P. (2008). Screening of antioxidant potential of selected barks of Indian medicinal plants by multiple in vitro assays. Biomed. Environ. Sci. 21(1): 24-29.

19. Neogi, U., Saumya, R., Mishra, R.K. and Raju, K.C. (2008). Lipid content and in vitro antimicrobial activity of oil seeds of some Indian medicinal plants. Curr. Res. Bacteriol. 1(1): 1-6.

20. Tarwadi, K. and Agte, V. (2005). Antioxidant and micronutrient quality of fruit and root vegetables from the Indian subcontinent and their comparative performance with green leafy vegetables and fruits. J. Sci. Food Agric. 85(9): 1469-1476.

21. Umamaheswari, M., AsokKumar, K., Somasundaram, A., Sivashanmugam, T., Subhadradevi, V. and Ravi, T.K. (2007). Xanthine oxidase inhibitory activity of some Indian medicinal plants. J. Ethnopharmcol. 109(3): 547-551.

22. Singh, G., Gupta, P., Rawat, P., Puri, A., Bhatia, G. and Maurya, R. (2007). Antidyslipidemic activity of polyprenol from Coccinia grandis in high-fat diet-fed hamster model. Phytomed. 14(12): 792-798.

23. Swamy, B.M.V., Kumar, G.S., Kumar, S.I.S., Suresh, H.M., Rajashekar, U. and Sreedhar, C. (2007). Antihepatotoxic effect of Coccinia grandis Linn, against carbon tetrachloride-induced hepatic damage in rats. Asian J. Chem. 19(4): 2550-2554.

24. Sunilson, J.A.J., Muthappan, M., Das, A., Suraj, R., Varatharajan, R. and Promwichit, P. (2009) Hepatoprotective activity of Coccinia grandis leaves against carbon tetrachloride induced hepatic injury in rats. Int. J. Pharmacol. 5(3): 222-227.

25. Umamaheswari, M. and Chatterjee, T.K. (2008). In vitro antioxidant activities of the fractions of Coccinia grandis L. leaf extract. African J. Trad. Complement. Alt. Med. 5(1): 61-73. 
26. Ogunbinu, A.O., Okeniyi, S.O., Flamini, G., Cioni, P.L., Ogunwande, I.A. and Olayinka, E.T. (2009). Essential oilbearing plants from Nigeria: studies on Vernonia perrottettii (leaf and stem bark), young leaves from Eucalyptus decaisneana and immature leaves of Hyptis suaveolens. J. Essen. Oil Res. 21(2): 154-158.

27. Grassi, P., Nunez, M.J., Reyes, T.S.U. and Franz, C. (2008). Chemical variation in the essential oil composition of Hyptis suaveolens (L.) Poit. (Lamiaceae). Nat. Prod. Commun. 3(7): 1137-1140.

28. Sensch, O., Vierling, W., Brandt, W. and Reiter, M. (2000). Effects of inhibition of calcium and potassium currents in guinea-pig cardiac contraction: comparison of $\square$-caryophyllene, eugenol, and nifedipine. Br. J. Pharmacol. 131(6): 1089-1096.

29. Edeoga, H.O., Omosun, G. and Uche, L.C. (2006). Chemical composition of Hyptis suaveolens and Ocimum gratissimum hybrids from Nigeria. African J. Biotechnol. 5(10): 892-895.

30. Tiwari, V.K., Rajwar, G.S. and Rawat, G.S. (1979). Protein and amino acid contents of Hyptis suaveolens Poit. J. Sci. Res. Plant Med. 1(1): 48-51.

31. Sairam, K., Hemalatha, S., Kumar, A., Srinivasan, T., Ganesh, J., Shankar, M. and Venkataraman, S. (2003). Evaluation of anti-diarrhoeal activity in seed extracts of Mangifera indica. J. Ethnopharmacol. 84(1): 11-15.

32. Lima, Z.P., Severi, J.A., Pellizzon, C.H., Brito, A.R., Solis, P.N., Cáceres, A., Girón, L.M., Vilegas, W. and HirumaLima, C.A. (2006). Can the aqueous decoction of mango flowers be used as an antiulcer agent $\square$ J. Ethnopharmacol. 106(1):29-37.

33. Zhang, L.L. and Lin, Y.M. (2009). Antioxidant tannins from Syzygium cumini fruit. African J. Biotechnol. 8(10): 2301-2309.

34. Ruan, Z.P., Zhang, L.L. and Lin, Y.M. (2008). Evaluation of the antioxidant activity of Syzygium cumini leaves. Molecules. 13(10): 2545-2556.

35. Mandal, S., Barik, B., Mallick, C., De, D. and Ghosh, D. (2008) Therapeutic effect of ferulic acid, an ethereal fraction of ethanolic extract of seed of Syzygium cumini against streptozotocin-induced diabetes in male rat. Methods Find. Exp. Clin. Pharmacol. 30(2): 121-128.

36. Sharma, B., Balomajumder, C. and Roy, P. (2008). Hypoglycemic and hypolipidemic effects of flavonoid rich extract from Eugenia jambolana seeds on streptozotocin induced diabetic rats. Food Chem.Toxicol. 46(7): 23762383.

37. Shinde, J., Taldone, T., Barletta, M., Kunaparaju, N., Hu, B., Kumar, S., Placido, J. and Zito, S.W. (2008). $\square-$ Glucosidase inhibitory activity of Syzygium cumini (Linn.) Skeels seed kernel in vitro and in Goto-Kakizaki (GK) rats. Carbohydr. Res. 343(7): 1278-1281.

38. Shankar, M.B., Parikh, J.R., Geetha, M., Mehta, R.S. and Saluja, A.K. (2007). Anti-diabetic activity of novel androstane derivatives from Syzygium cumini Linn. J. Nat. Remed. 7(2): 214-219.

39. Benherlal, P.S. and Arumughan, C. (2007). Chemical composition and in vitro antioxidant studies on Syzygium cumini fruit. J. Sci. Food Agric. 87(14): 2560-2569.

40. Ravi, K., Sekar, D.S. and Subramanian, S. (2004). Hypoglycemic activity of inorganic constituents in Eugenia jambolana seed on streptozotocin-induced diabetes in rats. Biol. Trace Elem. Res. 99(1-3): 145-155.

41. Bhatia, I.S. and Bajaj, K.L. (1975). Chemical constituents of the seeds and bark of Syzygium cumini. Planta Med. 28(4): 346-352.

42. Barthakur, N.N. and Arnold, N.P. (1991). Nutritive value of the chebulic myrobalan (Terminalia chebula Retz.) and its potential as a food source. Food Chem. 40(2): 213-219.

43. Khatoon, S., Singh, N., Srivastava, N., Rawat, A.K.S. and Mehrotra, S. (2008). Chemical evaluation of seven Terminalia species and quantification of important polyphenols by TLC. J. Plan. Chromatogr. 21(3): 167-171.

44. Kusirisin, W., Srichairatanakool, S., Lerttrakarnnon, P., Lailerd, N., Suttajit, M., Jaikang, C. and Chaiyasut, C. (2009). Antioxidative activity, polyphenolic content and anti-glycation effect of some Thai medicinal plants traditionally used in diabetic patients. Med. Chem. 5(2): 139-147.

45. Garg, A.N., Kumar, A., Nair, A.G.C. and Reddy, A.V.R. (2007). Analysis of some Indian medicinal herbs by INAA. J. Radio. Nuclear Chem. 271(3): 611-619.

46. Srikumar, R., Parthasarathy, N.J. and Devi, R.S. (2005). Immunomodulatory activity of Triphala on neutrophil functions. Biol. Pharm. Bull. 28(8): 1398-1403.

47. Naik, G.H., Priyadarsini, K.I., Bhagirathi, R.G., Mishra, B., Mishra, K.P., Banavalikar, M.M. and Mohan, H. (2005). In vitro antioxidant studies and free radical reactions of triphala, an ayurvedic formulation and its constituents. Phytother. Res. 19(7): 582-586.

48. Lee, Hyun-Sun., Won, N.H., Kim, K.H., Lee, H., Jun, W. and Lee, Kwang-Won. (2005). Antioxidant effects of aqueous extract of Terminalia chebula in vivo and in vitro. Biol. Pharm. Bull. 28(9): 1639-1644. 